
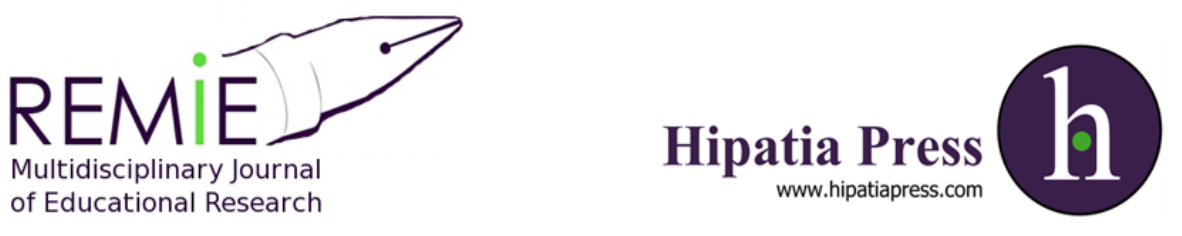

Instructions for authors, subscriptions and further details:

http://remie.hipatiapress.com

\title{
Developing Cooperative Learning Through Tasks in Content and
}

\section{Language Integrated Learning}

María del Carmen Ramos Ordóñez, Víctor Pavón Vázquez ${ }^{1}$

1) Department of English and German Philology, University of Cordoba, Spain.

Date of publication: June 15th, 2015

Edition period: June 2015 - October 2015

To cite this article: Ramos, M. C., \& Pavón, V. (2015). Developing cooperative learning through tasks in Content and Language Integrated Learning. Multidisciplinary Journal of Educational Research, 5(2), 136-166. doi:10.17583/remie.2015.1429

To link this article: http://doi.org/10.17583/remie.2015.1429

\section{PLEASE SCROLL DOWN FOR ARTICLE}

The terms and conditions of use are related to the Open Journal System and to Creative Commons Attribution License (CC-BY). 


\title{
Developing Cooperative Learning through Tasks in Content and Language Integrated Learning
}

\author{
María del Carmen Ramos Ordóñez Víctor Pavón Vázquez \\ University of Cordoba \\ University of Cordoba
}

\section{Abstract}

This article presents the results of a study on teachers' perceptions regarding specific work with tasks in the CLIL (Content and Language Integrated Learning) classroom, a context where academic content and a foreign language are learnt simultaneously. A questionnaire consisting of closed and open questions was administered to 25 teachers working in a school participating in an innovative project based on the implementation of tasks used as an instrument to promote cooperative learning. Following an interdisciplinary approach, the teachers worked in collaboration to design tasks that were organised and linked around a common topic. These crosscurricular themes were selected in the different subjects with the objective of making students work towards a common final goal through several developmental stages. The results of the study show that the teachers are concerned about the methodological difficulties that the use of tasks entail, about their own ability to cope with them, and about the problems that they encounter to collaborate. However, the teachers also value the benefits of this strategy in terms of achievement of learning objectives, and display a high degree of motivation to continue working with this model.

Keywords: bilingual education, CLIL, language learning, cooperative learning, task-based learning. 


\section{Desarrollo de Aprendizaje Cooperativo a través del Uso de Tareas en Aprendizaje Integrado de Lengua y Contenido}

María del Carmen Ramos Ordóñez University of Cordoba

\author{
Víctor Pavón Vázquez \\ University of Cordoba
}

\section{Resumen}

En este artículo se presentan los resultados de un estudio sobre las percepciones de los profesores con respecto al trabajo con tareas en un contexto de enseñanza AICLE (Aprendizaje Integrado de Lengua y Contenido), en el que los contenidos académicos y la lengua extranjera se aprenden de forma simultánea. 25 profesores participantes en un proyecto basado en la utilización de tareas como medio para fomentar el trabajo cooperativo completaron un cuestionario compuesto por preguntas cerradas y abiertas. De acuerdo con un enfoque interdisciplinar, los profesores trabajaron de forma conjunta para diseñar tareas organizadas y conectadas alrededor de un eje temático común. El objetivo era que los alumnos, a partir de elementos temáticos conectados entre las distintas asignaturas, trabajaran a lo largo de distintas fases para conseguir crear un producto final. Los resultados de este estudio muestran que el profesorado es consciente de las dificultades metodológicas que entraña el trabajo con tareas, de sus propias limitaciones para afrontarlo y de los problemas que en general supone establecer un modelo de colaboración entre ellos. Sin embargo, el profesorado también valora los beneficios de este tipo de trabajo aporta para la consecución de los objetivos de aprendizaje, además de mostrar un alto nivel de motivación para continuar trabajando de esta manera.

Palabras clave: bilingüismo educativo, AICLE, aprendizaje de lenguas, aprendizaje cooperativo, aprendizaje por tareas. 


\section{Ramos \& Pavón - Developing Cooperative Learning \& CLIL}

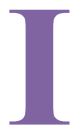

$\mathrm{n}$ the last two decades there has been an interest in implementing innovative educational methods particularly related to the teaching of content subjects in a foreign language (Eurydice, 2006, p. 8). Since the 1990s, "European programmes, educational legislative actions and other initiatives have resulted in various forms of curricular change as a result of integrating languages with content fields" (Marsh, 2013, p. 5), favouring the introduction of Content and Language Integrated Learning (CLIL) programmes as an approach to promote "innovative classroom pedagogies also in content subjects" (Dalton-Puffer, Llinares, Lorenzo \& Nikula, 2014, p. 215). CLIL is a teaching approach based on the learning of different curricular content areas through a foreign language: "CLIL is a dual-focused educational approach in which an additional language is used for the learning and teaching of content and language mastery to pre-defined levels" (Coyle, Hood and Marsh, 2010, p. 1). CLIL makes available opportunities for interaction "that are not typical in traditional foreign language teaching” (Dalton-Puffer, Nikula \& Smit, 2010, p. 279) and endorses the design of tasks with the objective of "engaging students' participation and interaction" (Escobar and Sánchez, 2008, p. 68).

The Andalusian Regional Government in Spain designed a linguistic policy following the principles defined in the Common European Framework of Reference for Languages (Council of Europe, 2001), and in 2005 launched the Plan to Promote Plurilingualism (Consejería de Educación, 2005). The objective was to achieve plurilingual and pluricultural skills, sequencing the contents of each stage of schooling and adapting assessment criteria to those established in the CEFRL, and fostering the development of oral and written skills within meaningful tasks and projects (Segovia et al. 2010, p. 155). In line with these recommendations, the school (Manuel Siurot, in La Roda de Andalucía) decided to implement a CLIL programme based on specific work with tasks, through which the students could learn curricular content and acquire command of the foreign language. The idea behind this proposal was that connecting subjects through the elaboration of tasks could beseem cooperative learning and, as a result, help develop interaction and facilitate the learning of content. In this study, we analyse the shortcomings of the implementation of tasks and cooperative learning in a CLIL context through the opinions of the teachers involved in the project. The objective is to identify the difficulties of this methodological strategy, and evaluate how teachers appreciate its implementation by reflecting on their own 
competences, problems encountered, and attainment of learning objectives, coordination measures, and motivation.

\section{Cooperative Learning}

Cooperative learning advocates a type of instruction where students work together in small groups to achieve a common goal. Sometimes cooperation is used as a synonym of collaboration; however, they are not exactly the same. While cooperative learning can be defined as "working together to accomplish shared goals" (Smith, 1995, p. 1), collaborative learning is "a method that implies working in a group of two or more to achieve a common goal, while respecting each individual's contribution to the whole" (McInnerney and Roberts, 2004, p. 205). In other words, cooperation can be achieved if all participants do their parts separately and bring their results to the rest of the group, while collaboration entails direct interaction among the students in the group "to produce a product and involves processes such as negotiations, discussions, and acceptance of the opinions of other group mates" (Kozar, 2010, p. 17).

Nevertheless, the line separating these two concepts is not so clear in practice and cooperative learning may also include the development of social skills, group reflection and interrelated work (Dillenbourg, Baker, Blaye \& O’Malley, 1996; Kagan, 1985; Roberts and MacInnerney, 2007; Roschelle and Teasley, 1995). Cooperative learning has become increasingly popular with benefits that include boosting students' interest, improving critical thinking, and the opportunity to practice both productive and receptive skills in a natural context (Casal, 2008). In a CLIL or language-learning context, the array of benefits extends beyond increased language learning to include increased self-esteem and tolerance of diverse points of view (Johnson and Johnson, 1989; Kagan, 1995; McCafferty, Jacobs \& Iddings, 2006; Slavin, 1995). Although cooperative learning has numerous variations, Johnson and Johnson (1989) indicate five features of a successful cooperative learning activity: (1) students learn that their success depends upon working together interdependently; (2) students are individually accountable while achieving group goals; (3) students support and assist one another's success through face-to-face interactions; (4) students develop social skills by cooperating and working together effectively; and (5) students as a group have the 
opportunity to reflect on the effectiveness of working together. When these principles are realised, cooperative learning creates a rich environment for students to learn language and simultaneously develop their capacities for communication and problem solving.

It has to be noted that the claim that cooperative learning differs from collaborative learning is based on the idea that the teacher adapts tasks and goals to the characteristics of the students in cooperative learning, whereas in collaborative learning the students negotiate with the teacher the mechanisms to achieve tasks' objectives (McWhaw, Schnackenberg, Schlater \& Abrami, 2003). In our view, both of them demand active involvement in the realization of tasks and are considered different facets of the same process. The general principles of cooperative learning establish the need for specific work with students in pairs and small groups (Long and Porter, 1985; Pica, Lincoln-Porter, Paninos \& Linell, 1996) so that they can help each other in the construction of meaning by using the language (Gillies, 2007). Cooperative learning can also be an impaired tool to prevent one specific danger typical of CLIL contexts, the potential drawbacks deriving from leaning too much towards receptive skills (listening and reading), therefore compromising the acquisition of productive skills (speaking and writing). As de Graaf, Koopman, Anikina and Westhoff (2007) and Casal (2008) point out, cooperative learning may in fact be a powerful strategy to counteract the negative effects of overusing receptive works in the CLIL classroom, because it proposes the use of the language not only to understand, but also to communicate and discuss by manipulating the content matter.

\section{Learning through Tasks in Content and Language Integrated Learning}

It is stated in Chapter 2 of the Common European Framework of Reference for Languages (Council of Europe, 2001) that the methodological approach based on action through tasks is the most effective one for the development of communicative competences that are needed by individuals. Willis (1996, p. 23) defines a task as an activity in which the language is used for a communicative purpose "to accomplish an outcome". Skehan (1998) observes that tasks are activities in which meaning is primary, there is a communicative problem to solve, there is a situation comparable to realworld activities, the stress is on communicative code and not on the linguistic form, task completion is a priority, and they are assessed in terms of an 
identifiable outcome. The most common characteristic of working with taskbased learning is the focus on authentic use of language for meaningful purposes (Willis \& Willis, 1996, 2007).

The focus on the elaboration of tasks brings about notable benefits to the learning of English as a foreign language and is particularly relevant in CLIL because of the emphasis on "problem-solving" (Navés \& Muñoz, 2000, p. 2), even though the conditions may not be ideal: "task-based learning can favour participation and interaction in a CLIL context where students have low linguistic proficiency" (Pavón, Prieto and Ávila, 2015, p. 85). In fact, the relationship between task-based learning and CLIL can be defined as "symbiotic" (Meyer, 2010, p.19) due to the use of authentic and meaningful content. In the context of this study, communicative tasks are a pivotal strategy in CLIL, in that they really promote cooperative learning: "A lot of what goes on in the CLIL classroom involves practical application of knowledge through problem solving tasks and cooperative learning" (Pavón and Ellison, 2013, p. 71). Working with tasks provides a richer learning experience as it entails working through different subjects in a more realistic way: "Students learn knowledge and elements of the core curriculum, but also apply what they know to solve authentic problems and produce results that matter" (Markham, 2011, p.38). Also, students have a more active role in their own learning and in the learning of the rest of their classmates: "the students not only learn from their teachers but also from the other students" (Pastor, 2011, p.112). The objective is to attain linguistic or communicative competence as the result of the fusion between formal (linguistic) and instrumental (communicative) knowledge, two dimensions that have to be constructed in an interrelated way: "The key to successful learning is to find ways of weaving together formal and instrumental knowledge" (Estaire and Zanon, 1994, p. 77).

In order to weigh the efficiency of models, methodologies and strategies in CLIL, it is essential, together with the analysis of the structure of tasks and of interaction, to take an insight into "the students' perceptions and teachers' mind-sets" (Bonnet, 2012, p. 87). With regard to the analysis of the beliefs that teachers possess of their own performance, it has to be said that knowledge of this area definitely contributes to sketch the ideal conditions for the application of any given teaching methodology. The way they have been taught and their implicit theories about teaching are by far the most 


\section{Ramos \& Pavón - Developing Cooperative Learning \& CLIL}

influential factors determining their pedagogy, and the same can be said when investigating their role in CLIL: "When it comes to bilingual teachers, their personal baggage, knowledge and concept of bilingualism is of vital importance" (Pena \& Porto, 2007, p. 153). This means that investigating the personal experience of the CLIL teacher and the fashion they adopt to shape teaching brings about a fine understanding of their role in the teaching process (Meyer, 2010, p. 13). Reflection on their own practice will play a part in their own professional development (Guazzieri, 2008, p. 78), this way contributing to develop a finer version of the methodology used. Teachers' own perception of their work is a deciding factor for the success of CLIL, as teachers are responsible to provide adequate support by scaffolding students' negotiation of meaning (Bonnet, 2012, p.182), and scaffolding is necessary to provide the appropriate support to structure and accomplish tasks (Meyer 2010, p. 15).

\section{Research Design}

\section{Objectives and Research Questions}

The main objective of this study is to analyse the perceptions of teachers involved in bilingual education about the use of cooperative learning and tasks, and if working in this way may bring about more involvement by students in the learning process. The independent variables are cooperative learning and tasks, which represent the phenomena that we are going to analyse in order to determine the effects and changes that they produce in the studied context. The dependent variables are the students' participation and involvement in the learning process and the teachers' reflections as they represent the means that measure these changes.

The research questions posited in this study are the following:

1) Do teachers feel confident when working with cooperative learning and tasks?

2) What are the difficulties of adopting cooperative learning strategies and tasks with Primary Education students?

3) Are tasks and cooperative learning an effective way to promote students' involvement and to achieve the learning goals?

4) Is coordination between teachers a key factor for the promotion of cooperative learning? 
5) Are teachers motivated for the introduction of cooperative learning and tasks in their teaching and learning practices?

\section{Characteristics, Context and Participants}

Since the general objective of this study is to determine if the use of cooperative learning and tasks bring about more involvement of the students in the learning process, this research can be considered applied and practical at the same time, according to the classification of research in second language acquisition determined by Seliger and Shohamy (1989) in three categories: basic or theoretical, applied and practical. It is applied because we are trying to test if, according to teachers, the use of cooperative learning during the implementation of tasks has a positive influence on students' performance in the classroom. It is practical because in the course of the research, teachers have incorporated tasks in their actual practices in order to promote cooperative learning strategies.

This study was carried out during the academic year 2012/13 in the school Manuel Siurot, a Pre-school and Primary School in La Roda de Andalucía, Seville. Most of the students come from families of a medium to low socioeconomic level, though the entire social stratification is present, since this is the only pre-school and primary school in the town. In all the classes there are students of ethnic minorities from Romania and Morocco, and a small representation of South American nationalities. A total 25 teachers participated in the study, from the areas of English, Music, Physical Education, Science, Religion, Language and Speech Therapy, and Therapeutic Pedagogy.

\section{Data Collection: Instruments and Procedure}

Table 1

Instruments

\begin{tabular}{lll}
\hline Classification of instruments & & \\
\hline Semi-structured questionnaires & $>$ & Teachers' questionnaire \\
Record reviews & $>$ Colabor@ Platform \\
\hline
\end{tabular}




\section{Ramos \& Pavón - Developing Cooperative Learning \& CLIL}

In this research, an eclectic approach with quantitative and qualitative methods has been used in an attempt to provide an accurate description of the area of research. Semi-structured questionnaires included several dimensions with a narrow range of possible answers and items with open questions. The reason for including open questions was to find specific characteristics of the phenomena as teachers perceived them. It was important to include both quantitative and qualitative data because the subjective data gathered from qualitative research helps to explain and describe elements from reality that are difficult to quantify:

We see most value in investigations that combine objective and subjective elements, that quantify only what can be usefully quantified, and that utilise qualitative data collection and analysis procedures wherever they are appropriate. (Allwright and Bailey, 1991, p. 67).

The researcher administered the teachers' questionnaire at the end of the academic year 2012-13, a time of the year where they could be more relaxed once classes with students had finished and they did not have to correct tests, prepare classes, attend to parents and write up school documents and on-line reports. One of the concerns about using questionnaires was that there could be a low rate of return. In this research, despite the fact that questionnaires were given to the teachers at the end of the year, the return rate was of a $92.59 \%$.

The second instrument for data collection was the Colabor@ Platform, a digital collaborative tool created by the Andalusian educational authorities to keep a record of the information and documents that are shared by teachers participating in educational projects. For the purpose of this research, the relevant data were the opinions, impressions and experiences of the teachers once they had been trained in the understanding and implementation of cooperative learning strategies in their classes. These data were collected in the last task of the training project, where teachers were asked to reflect on the general benefits and difficulties that using tasks entails. The researcher has used these data to triangulate with the opinions stated by teachers in the questionnaires. 


\section{Data Analysis and Discussion}

The data is classified and presented in five dimensions: teachers' confidence and competences; difficulties of working with tasks; the connection between cooperative learning, tasks and learning goals; the role of coordination of teachers in the design and implementation of tasks; and motivation on the part of teachers to work with tasks. The findings are presented and analysed quantitatively and qualitatively using the data provided by the two different instruments. The results that can be analysed quantitatively are depicted graphically, either in tables or in bar diagrams. Qualitative analysis is illustrated by quotations from teachers. In order to identify the teachers, they are represented with a ' $\mathrm{T}$ ' followed by a number.

\section{Teachers' Confidence}

In the questionnaire that was administered to the teachers, they were asked in questions 1 and 2 if they felt qualified to teach through tasks and if they had ever worked in this way. The results were that $88.23 \%$ answered that they did not feel qualified and only 11.76 answered they were. The argument for all the teachers who answered negatively and who thought that they did not feel confident and had doubts about how to work through tasks, not only in the planning phase but also in their implementation, was that they were not qualified for that type of teaching. On the other hand, it is interesting to note that the teachers who stated they were confident were teachers who had previously worked in pre-school levels:

T2. We could say that in pre-school education we work through tasks since the centres of interesting which we work encompass all areas. The only difference is that we don't present a final product.

T3. It has not been very difficult for me, since in pre-school education we work from in a collaborative way. The first didactic units were done quite a long time ago for the first cycle and it helped me to understand the concept of task. 


\section{Ramos \& Pavón-Developing Cooperative Learning \& CLIL}

Obviously, teachers who had received specific training in cooperative learning and use of tasks, and who had worked in a similar way in the past, also felt reasonably comfortable:

T5. I didn't feel a hundred per cent secure, but designing tasks in cycle meetings and with my colleagues, the training that we have received along these two last years, and the fact that we progressively assimilate tasks in our daily work, all this, has helped me not to feel lost and to put them into practice with success.

T23. This last year I have more confidence. Though I have a lot to learn and improve I have clear ideas.

All in all, teachers concur that it is necessary to have more training to feel confident enough:

T8. I had many doubts, lack of training and even lack of conviction. However, I think I have overcome that phase and now I feel the opposite side. I feel the need to improve in this type of work.

T17. Since in the last year we worked through tasks, this year I have felt more comfortable but I don't feel trained enough.

The stability of the teaching staff is considered essential, as for most of them this methodology is new and they had not experienced the training and implementation of tasks in the previous academic year:

T13. It was my first year in the school and I didn't feel qualified because I have never worked like this before ... and furthermore, there was lack of information on the part of the teachers that had already worked in the school.

T23. Sincerely, the first year I didn't feel qualified to put into practice tasks since that was the first time I worked as a teacher.

\section{Difficulties}

Teachers were asked about the greatest difficulties that they faced when teaching through tasks (question 3). In line with the opinions in the previous 
section, teachers agree that training, and also commitment on their part, are essential to help them gain confidence in their daily practice:

T8. I didn't feel qualified but my own desire to improve and the wish to innovate and to know new methodologies have made me feel very comfortable accomplishing tasks.

Teachers also state that having an unstable staff implies the need for continuous training to support new teachers, and this affects coordination negatively. Although teachers have some slots in their schedules to coordinate with the rest of the teachers, they think that this is not enough:

T14. The problem would be solved if the staff in the school were permanent.

Teachers consider that they need plenty of time to develop the activities that they design and that it is very complicated if the students are young. To overcome this it is very important that teachers design activities suitable for the students' age and also teach them how to work cooperatively in order to make projects:

T14. Lack of time to get adapted to the rhythm of the class, a situation which worsens when there is no cohesion in the group.

T19. It's difficult to implement with young students because they are not autonomous.

In pre-school education, it is very common to ask parents to work with their children at home and even to participate in the school activities. Sometimes families collaborate with the school in storytelling activities or to help the teachers with some projects, but in primary education the situation is different. There is a great change in the way students work as in primary education they usually sit individually or in pairs, whereas in pre-school students sit in groups to work cooperatively in the projects that they are involved in. When students in primary education are arranged in teams to work cooperatively within tasks, some families do not support this initiative: 
T11. The family doesn't support group work because of personal reasons, and this makes our task even more difficult than it is.

Other problems are generated by the great diversity of students, which brings about two important considerations: firstly, the degree of participation and engagement in the group activities; and secondly, the adaptation of the design of the tasks and goals to the diversity of students:

T13. Most students work in the right way, but some of them delegate responsibilities to the others and they don't get involved.

T10. Most students progress favourably though there are cases where even being good students don't get the results they should for their level.

This last quotation points out something crucial, that this is a methodology that requires more time both for the teachers and for the students. Students need to be comfortable connecting ideas and contents from different subjects. Also, diversity is a reality. There are students with different levels in every single class. We might find students who require curricular adaptation and they are following a programme of reinforcement to overcome their learning difficulties, either because they have learning difficulties, they have been incorporated late into the Spanish educative system, they suffer from behavioural problems or syndromes such as attention deficit disorder, with or without hyperactivity, autism, Asperger's syndrome, etc. With this variety of students, teachers have to design the activities sensibly and with great sensitivity to student needs so that they may be able to participate within groups. Cooperative work can be a powerful aid for these students since working with other students may help them achieve success. However, this is not always possible:

T24. I encounter difficulties if we don't take into account the diversity of students: level of difficulty, means of presenting the contents, adaptation to different characteristics, interests and abilities of each student. It requires perseverance, dedication and effort on the part of all the teachers involved. 
T22. Each student is unique and for that reason needs an individualized programme.

T25. Cooperative learning needs to be adapted to the student's characteristics and needs, and this is not always possible.

Another issue is the alteration of the classroom dynamics. The fact is that working in small groups implies a great change. Students have to follow some rules. They need to organise themselves and follow guidelines. Often noise increases in the class, and sometimes this may cause lack of concentration in some students:

T18. What I don't like is the noisy atmosphere that group-work produces.

T8. We are afraid to change because we lose our leading role in the class. However, I think that with this system our role acquires another dimension. All those shortcomings and difficulties can become our ally and create an ideal atmosphere in our classes.

Therefore, it is evident that students need to be instructed to work in teams in order for the teaching-learning process to be successful. It is necessary to group the students in cooperative teams to implement tasks, and this requires a lot of preparation. First, compatibility among students is necessary. They need to know each other, to know what their classmates' skills are, their weak and their strong points, and to know how to organise themselves within the group to accomplish the tasks successfully. In order to achieve that cohesion and to strengthen the relationship among students, teachers need to start the school year doing a study of their social relationships and put into practice classroom dynamics:

T15. It is essential to have a class of students that allow you to do this type of activity. The biggest difficulty is in the cohesion of the group.

Finally, teachers were asked in questions 4 and 6 if they were able to achieve the goals in all the tasks, and if not, to identify the reasons. Only $33.4 \%$ of the teachers answered that they could carry out the task, and $66.6 \%$ 
answered they could not. The reasons they gave are expressed in percentages in the following table:

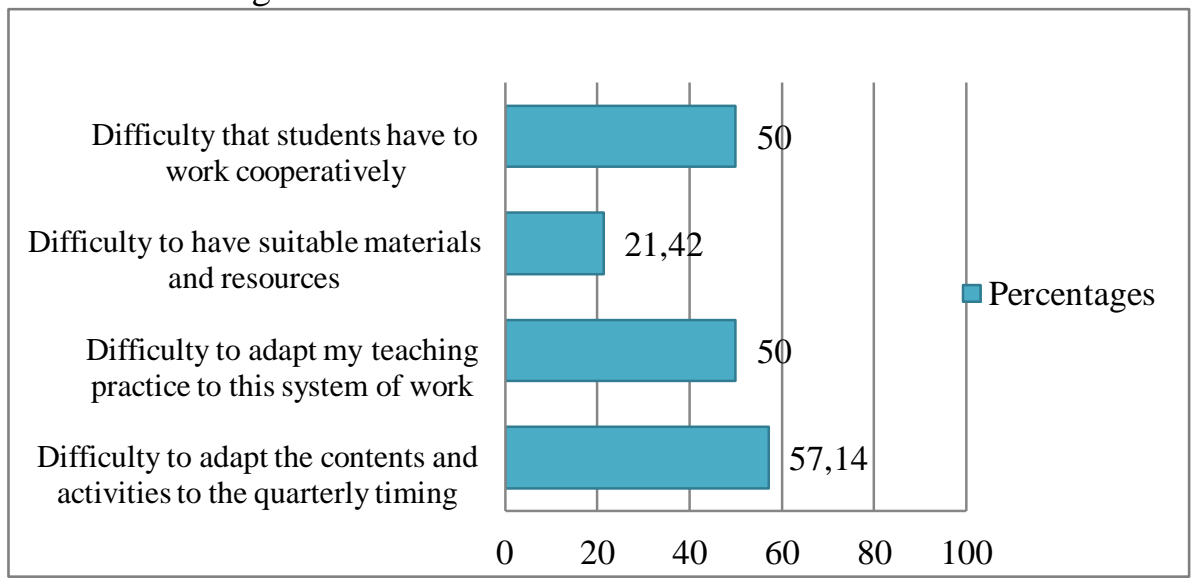

Figure 1. Reasons

Around $50 \%$ of teachers state that they could not carry out all the final projects because of three main reasons: the difficulty students have in working cooperatively, the teachers' lack of practice of this methodology, and the lack of time to carry out all the activities within the frame. Once more we find that it is essential to adapt the curriculum and activities to the context and make planning more realistic. In addition, working with tasks may create anxiety and the feeling that things do not work as they should.

However, the evaluation of working with tasks and cooperative learning is not so negative. Despite all the difficulties, teachers are also aware of the benefits. When they answered question 3 the following advantages were highlighted: this kind of work is more dynamic; the student is the core of his/her learning; and it favours more meaningful and contextualized learning:

T23. Students acquire basic competences and meaningful learning... we integrate several areas of knowledge, generating meaningful learning and encouraging cooperative work where each student contributes the best he/she can to the rest of the group.

As was explained in section 3.3, teachers had to log into the Colabor@ Platform in order to accomplish several tasks during the training period and 
to reflect and share ideas with all the teachers that were participating in the training programme. These tasks were also used to assess the development of the training activity. During the fulfilment of these different tasks, teachers commented appreciatively on their own work in relation to the implementation of tasks and cooperative learning with their students. A summary of the answers of all the teachers is shown in the following table:

\section{Table 2}

Teachers'opinions in Colabor@Platform

Teachers' opinions about the Difficulties and Benefits of Cooperative Learning

Difficulties

- Some students "delegate" their work to their mates and they do not get involved in teamwork or they prefer to do the tasks individually without sharing their results.

- It is important to make the families aware of the importance of cooperative work. Some of them think that "team work" is a loss of time.

- There are many doubts at the beginning of implementing cooperative learning, which suggests that specific training is needed.

- Sometimes, there is not enough time to coordinate with other teachers.

- Students need to talk about their tasks, they ask many questions, they make noise, and sometimes there is an apparent disorder in the class. Teachers have to assume and accept this with normality.
Benefits

- Students feel more confident in their answers and their selfesteem rises.

- Autonomy and motivation are reinforced.

- It is strengthened that students improve their own results but also the results of his/her teammates.

- Shared responsibility and students' relationship are favoured by promoting respect towards the others.

- It favours oral expression, turntaking, and general communication in class.

- Students have an active role in their learning process.

- It favours activities where "inclusion" is possible, though with certain difficulties, 


\section{Ramos \& Pavón - Developing Cooperative Learning \& CLIL}

As can be seen, the comments made by the teachers while completing the different tasks during the training period coincide almost entirely with the answers provided by questions 3, 4 and 5 in the questionnaire concerning the difficulties of carrying out tasks once the academic year had finished. More specifically, teachers addressed the difficulties arising from: the necessity to possess a solid understanding of the characteristics and methodology of tasks and cooperative learning; the involvement of students in the realisation of tasks; the appearance of some class management problems; the absence of the necessary time to coordinate with other teachers; and the lack of understanding on the part of the families of the nature and benefits of this kind of work. However, as revealed in the questionnaire, teachers could also perceive a series of positive outcomes deriving from the use of tasks and the promotion of cooperative learning, especially in the domain of psychoaffective factors, with an increase in their self-esteem, motivation and interest in what they were doing, and in the promotion of autonomy and responsibility within the group.

\section{Learning Goals}

The degree of success of the implementation of tasks and cooperative learning is measured by the reports that teachers make of the degree of achievement of the objectives by the students and of the students' involvement. To analyse this dimension within the assessment of the programme, we have used the data provided by the teachers in questions 6,7 , and 8 of the questionnaire.

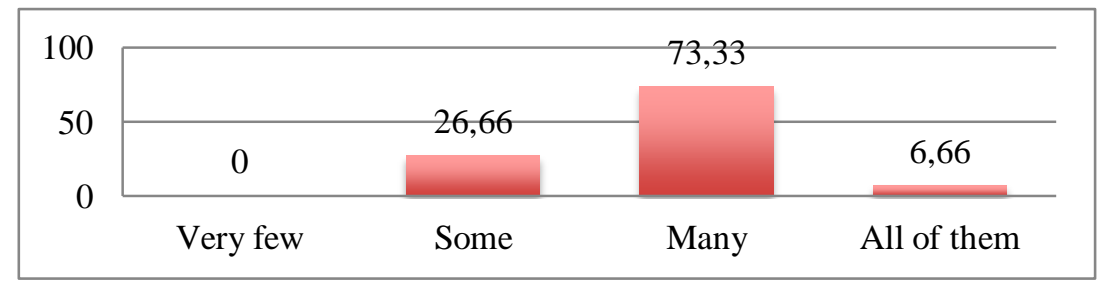

Figure 2. Achievement of didactic objectives

The results are highly positive in global terms when it comes to the evaluation of the degree of achievement of didactic objectives in tasks (question 6). According to teachers, the number of students that reach all the 
objectives is $6.66 \%, 73.33 \%$ of students achieve many of the objectives, and only $26.66 \%$ reach some of the objectives. Therefore, we can say that the perception that teachers have is that the students' results are high and the achievement of the learning objectives is reasonably positive.

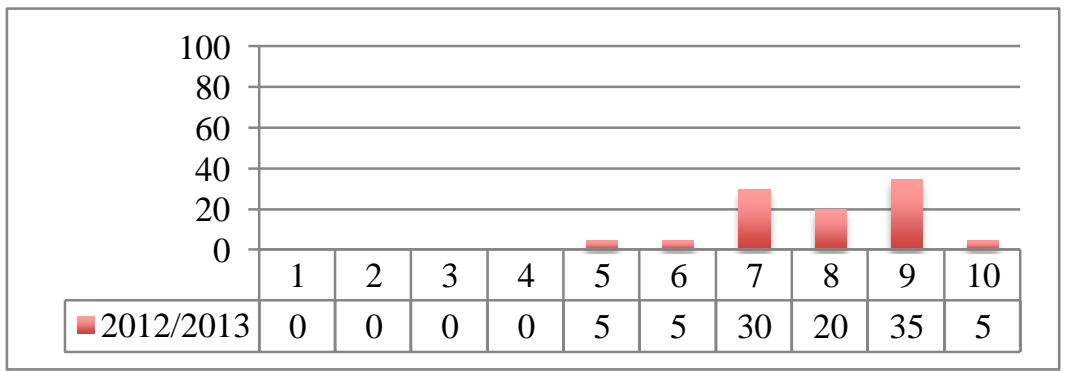

Figure 3. Students' involvement

In terms of the appreciation of the students' involvement (question 7), teachers value working with this type of methodology. $85 \%$ of the teachers consider that the degree of involvement of working with tasks is between 7 and 9 out of 10 , with 9 being the most frequent value (35\%). Only 5\% give it with a 6 or a 5 , and nobody thinks working with tasks produces little or no involvement on the part of the students (below 5).

\begin{tabular}{|c|c|c|c|}
\hline \multirow{5}{*}{$\begin{array}{r}100 \\
80 \\
60 \\
40 \\
20 \\
0\end{array}$} & & & \\
\hline & & & \\
\hline & & & \\
\hline & & & \\
\hline & Very little & Something & A lot \\
\hline Listening & 0 & 50 & 50 \\
\hline Speaking & 14,29 & 50 & 35,71 \\
\hline Reading & 0 & 57,14 & 42,86 \\
\hline Writing & 7,15 & 57,14 & 35,71 \\
\hline Interaction & 14,29 & 50 & 35,71 \\
\hline
\end{tabular}

Figure 4. Skills improvement 
With regard to the analysis of the skills that teachers perceive that are being promoted with the use of tasks (question 8), again the evaluation is positive since all the linguistic skills, including interaction, improve significantly ("a lot") for more than two thirds of the teachers. The perception then is that the majority of the teachers believe that all the linguistic skills improve with the use of tasks. In fact the total number of teachers state that listening and reading always improve, and only a minority think that speaking (14.29\%), writing (7.15\%) and interaction (14.29\%) improve very little.

\section{Coordination}

Teachers had already identified (in question 4) the need for coordination as one of the difficulties for the implementation of cooperative learning, and in questions 9 and 10 were specifically requested to give their opinions on the existence of coordination between teachers and on the types of coordination established.

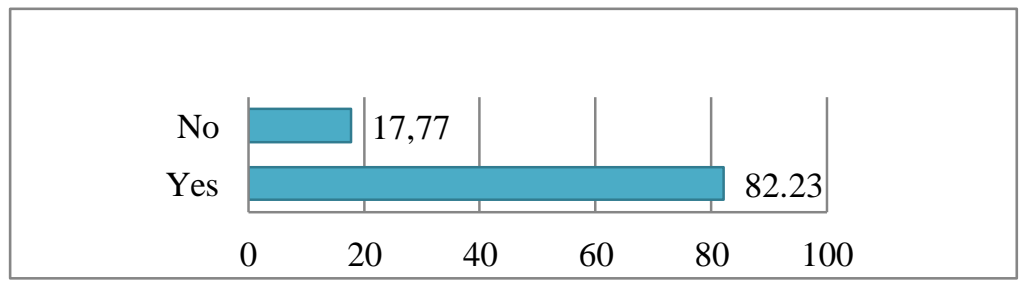

Figure 5. Teacher's coordination

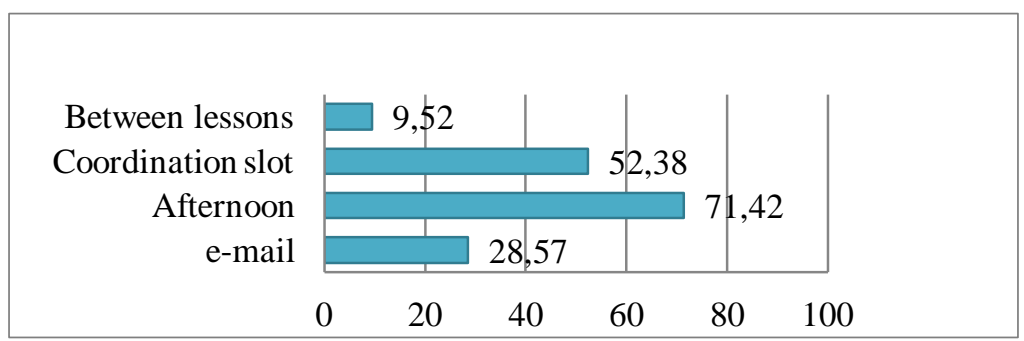

Figure 6. Possibility to coordinate 
The majority of teachers stated that they coordinated with other colleagues $(82.23 \%$ vs. $17.77 \%$ who did not coordinate), viewing coordination as a fruitful activity that can prepare them for further promotion of cooperative work with students:

T20. In addition to implementing coordination schedules, we should improve its use, practising cooperative work among ourselves.

As for the way in which teachers were carrying out coordination, they mentioned four different means to structure it: between lessons, using specific slots in their schedules, during the afternoon, and via e-mail. It is interesting to note that, even though there are special slots in the schedule for the teachers to coordinate (52.38\% of them make use of that), the time allowed for these meetings is not enough, and the majority of teachers $(71.42 \%)$ have to make use of the afternoon time to meet with colleagues for coordination:

T13. During the afternoon schedule due to the amount of paperwork and to meetings, there hasn't been enough time to coordinate.

T19. With the tutor of the other group in the coordination slot, but it was not enough time (only 45 minutes), and only sometimes in the afternoon meetings.

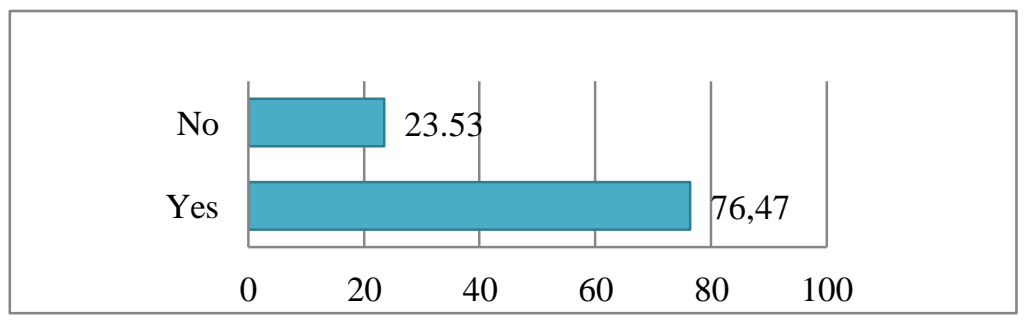

Figure 7. Coordination with language assistants

$76,47 \%$ of teachers state that they coordinate with the language assistants to prepare the classes, although they believe that they would need to improve coordination and devote more time to it. $23,53 \%$ of teachers do not coordinate with the language assistants, and in this case, what they do is just 


\section{Ramos \& Pavón - Developing Cooperative Learning \& CLIL}

follow the activities of the textbooks without previous planning. When there is coordination between the teacher and the language assistant, sometimes the language assistant follows the activities that are programmed in the books, whereas in other classes they bring their own ideas (mainly games to practise oral skills) taking into account the contents that students are learning at that moment. Following one or another's lesson planning, depends on the freedom that the teacher gives the language assistant to innovate and do what they consider best:

T11. We explained to her how we worked and sometimes she prepared worksheets or games related to the topic.

T15. I planned the lessons and the language assistant did what I told her.

They coordinate in breaks or in the class when they change from one lesson to another and some of them use e-mails, but they do not have a specific slot in their schedules to coordinate with the language assistants:

T13. I think it is necessary to establish sessions for bilingual coordination with the language assistant in the schedule so as to encourage such coordination.

T19. Not much. It was limited to short periods of time in the breaks or when she came to class and I explained then what I wanted her to do for the next lesson.

As we see, there is not a specific time devoted to coordination with the language assistants and this implies that they are not properly used because if content teachers had more time to work cooperatively and collaboratively with the language assistants, they could design activities carefully which might be different to the ones that are traditionally included in the textbooks and encourage more enriched learning activities for students.

\section{Motivation}

Teachers expressed their level of motivation towards this project and their opinion about the continuity of it in question 11: 
T8. I'm convinced of its efficiency and of the clear improvement that we'll have with our students.

T9. I think it is positive to work through projects and that teachers should improve in the implementation of them.

Despite the difficulties previously analysed, almost all the teachers in the school were positively motivated though to different degrees, depending on the difficulties or problems that they had in their particular classes:

T13. Students are more autonomous and the time to correct activities is reduced, therefore it is possible to better attend to students with learning difficulties.

T18. My students have fewer behavioural problems than in the previous year.

The global perception is that the majority believed that it would be positive to continue with the implementation of tasks:

T7. My highest motivation is to continue with the practice of this type of methodological project, with great enthusiasm, since students like it a lot. It's a playful way to teach and learn and I hope to experiment with new ideas.

Only one teacher gave a completely negative opinion towards this project, an opinion that should be carefully analysed:

T14. A lot of work to get poor results. The administration doesn't pay for our effort. We leave aside key contents for future learning (calculus, memorization, study techniques, grammar). Nowadays, everything is based on social issues, groups, etc., nullifying individuality. Everything is politics.

It has to be highlighted that this is an opinion of a teacher of a class of students with many special educational needs, where there was no cohesion among the group, and there were students who had behavioural problems. In addition, we can identify in those words that there is a misunderstanding of 
what a task is. Working through tasks does not mean that students are not going to study calculus, study techniques or grammar. All of them are, and must be included, in the didactic planning of tasks. The purpose of tasks is to look for the connection between different areas to teach students in a meaningful way. Working in cooperative groups does not mean neglecting individual tasks, as both coexist within the dynamics of the classroom.

\section{Conclusion}

This study examines the teachers' perceptions on cooperative learning and tasks. First of all, this research confirms the assumption that using tasks is a suitable strategy to promote cooperative learning in a CLIL context (Coonan, 2012; Dalton-Puffer et al., 2010). At the same time, the findings of this study reveal that tasks may be an ideal condition for the integration of content and languages since the students' degree of engagement increases (Berton, 2008; Guazzieri, 2008), and they promote meaningful learning connected with students' interests and motivation (Heras and Lasagabaster, 2015; Poisel, 2012).

More particularly, the findings with respect to the research questions formulated are that some teachers may not feel confident when working with cooperative learning and tasks, not only due to the complexity of the enterprise, but mainly because of the lack of experience with the implementation of a pedagogical approach that is new and unknown to many of them. Teachers stated that specific training on these areas is required, and also that the stability of staff is a key factor in helping structure collaboration and cooperation between teachers. Secondly, teachers described a number of difficulties that could seriously harm the work with tasks and the promotion of cooperative learning: again, stability of staff; the increase of time that these strategies demand; the difficulty to engage students and to foment group cohesion with very different class dynamics; the lack of cooperation from families; and more importantly, the great diversity of factors related to students. But at the same time, they could notice some benefits, such as the move to learner-centred teaching, the move towards more meaningful and contextualised learning, and the increase in students' motivation, interest and self-esteem. Thirdly, tasks and cooperative learning seem to effectively endorse the achievement of learning goals and the promotion of the students' involvement, as the majority of teachers reported that students were able to 
attain the learning objectives, and that there was a significant improvement in the language skills. Fourthly, the majority of teachers understand the potential and the necessity to coordinate with other teachers and with the language assistants when working with tasks, although they identified the short time devoted to gathering together as a hindrance that impairs agreed planning of activities which can seriously hamper coordination. Finally, teachers seem to be truly motivated towards the introduction of cooperative learning and tasks in their teaching and learning practices, and, despite all the difficulties, they see them as powerful pedagogical tools that can enrich the students' learning process and the teachers' own professional development.

A first general pedagogical conclusion is that, in the case of cooperative learning, teachers have to facilitate group cohesion through group dynamics (Dörnyei, 1997), so that they can organise their classes into groups or teams. It is when teams are formed, when students have to assume different roles within the team so that they engage in a process of cooperative learning. A second major conclusion is that cooperative interaction processes within the classroom are essential, but those processes cannot be isolated. They have to be developed within a parallel, transversal system of common pedagogical guidelines for the whole school (Pérez-Cañado, 2014). It should not be an isolated initiative of one teacher, but on the contrary, all teachers in the school should incorporate the same pedagogical guidelines in their classes (Pavón, Ávila, Espejo \& Gallego, 2014). Therefore, cooperative work has to extend beyond the limits of the classroom to the whole educational community. Teachers have to cooperate and collaborate in all the phases of the teaching learning process, which consists of cycles of analysis of the situation, design of curricular programmes, implementation of those programmes, evaluation, and design of new strategies of didactic intervention. If teachers engage in this cooperative cycle, the results will be successful and they will be able to achieve their objectives.

Finally, it has to be noted that this is an investigation with natural groups and for that reason there are variables such as students' sex, age and particular characteristics that are difficult to control. As a consequence, it might be possible that in another school context the results are different. Concerning possible lines of future research, an experimental approach could be used to test how strategies of cooperative learning contribute to the development of each one of the five linguistic skills, for example. Also, 
160 Ramos \& Pavón - Developing Cooperative Learning \& CLIL

similar studies could be complemented with class observation, and with the analysis of how to integrate students with specific needs, a controversial issue that would require a deeper level of analysis.

\section{Acknowledgments}

The authors wish to express their sincerest gratitude to the teachers of the Pre-school and Primary School "Manuel Siurot" (La Roda de Andalucía, Sevilla, Spain) for their willingness to participate in this study.

\section{References}

Allwright, R., \& Bailey. K.M. (1991). Focus on the Language Classroom. Cambridge: Cambridge University Press.

Berton, G. (2008). Tasks, Learning Activities and Oral Production Skills in CLIL Classrooms. In M. Coonan (Ed.), CLIL e l'Appredimento delle Lingue. Le Sfide del Nuovo Ambiente di Apprendimento (pp. 143-151). Venezia: University Ca' Foscari, Venezia.

Bonnet, A. (2012). Language, Content and Interaction: How to Make CLIL Classroom Work. In D. Marsh, O. Meyer (Eds.), Quality Interfaces: Examining Evidence \& Exploring Solutions in CLIL (pp. 172-189). Eichstätt: Eichstätt Academic Press.

Casal, S. (2008). Cooperative Learning in CLIL Contexts: Ways to Improve Students' Competences in the Foreign Language Classroom. Paper presented in the IAIE Conference Cooperative Learning in Multicultural Societies: Critical Reflections. Turin. Retrieved from http://soniacasal.wordpress.com/2008/10/18/cooperative-learning-inclil-contexts-ways-to-improve-students-competences-in-the-foreignlanguage-classroom/

Consejería de Educación de la Junta de Andalucía (2005). Plan de Fomento del Plurilingüismo [Plan to Promote Plurilingualism]. Seville: Junta de Andalucía. Retrieved from

http://www.juntadeandalucia.es/averroes/plurilinguismo/

Coonan, C. M. (2012). Affect and Motivation in CLIL. In D. Marsh and O. Meyer (Eds.), Quality Interfaces: Examining Evidence \& Exploring Solutions in CLIL (pp. 52-659). Eichstätt: Eichstätt Academic Press. 
Council of Europe. (2001). Common European Framework of Reference for Languages: Learning, Teaching, and Assessment. Cambridge: Cambridge University Press.

Coyle, D., Hood, P., \& Marsh, D. (2010). CLIL Content and Language Learning. Cambridge: Cambridge University Press.

Dalton-Puffer, D., Nikula, T., \& Smit, U. (2010). Language Use and Language Learning in CLIL: Current Findings and Contentious Issues. In C. Dalton-Puffer, T. Nikula \& U. Smit (Eds.), Language Use and Language Learning in CLIL (pp. 279-291). Amsterdan: John Benjamins.

Dalton-Puffer, C., Llinares, A., Lorenzo, F., \& Nikula, T. (2014). You Can Stand Under My Umbrella: Immersion, CLIL and Bilingual Education. A Response to Cenoz, Genesee and Gorter (2013). Applied Linguistics, 35(2), 213-218. doi:10.1093/applin/amu010

Dillenbourg, P., Baker, M., Blaye, A., \& O'Malley, C. (1996). The Evolution of Research on Collaborative Learning. In E. Spada \& P. Reiman (Eds.), Learning in Humans and Machine: Towards an Interdisciplinary Learning Science (pp. 189-211). Oxford: Elsevier.

Dörnyei, Z. (1997). Psychological Processes in Cooperative Language Learning: Group Dynamics and Motivation. The Modern Language Journal, 81(4), 482-493. doi:10.1111/j.1540-4781.1997.tb05515.x Escobar, C., \& Sánchez, A. (2009). Language Learning Through Tasks in a Content and Language Learning (CLIL) Science Classroom. Porta Linguarum, 11, 65-83.

Estaire, S., \& Zanon, J. (1994). Planning Classwork: a Task-based Approach. England: Heinemann.

Eurydice. (2006). Content and Language Learning (CLIL) at School in Europe. Brussels: European Commission.

Gillies, R. (2007). Cooperative Learning: Integrating Theory and Practice. Los Angeles, CA: Sage.

de Graaf, R., Koopman, G.J., Anikina, Y. \& Westhoff, G. (2007). An

Observation Tool for Effective L2 Pedagogy in Content and Language Integrated Learning (CLIL). The International Journal of Bilingual Education and Bilingualism, 10(5), 603-624.

Guazzieri, A.V. (2008). Oral Interaction in CLIL Student-led Cooperative Group Work. In C.M. Coonan (Ed.), CLIL e l'Appredimento delle 
162 Ramos \& Pavón-Developing Cooperative Learning \& CLIL

Lingue. Le Sfide del Nuovo Ambiente di Apprendimento (pp. 79-1039. Venezia: University Ca' Foscari, Venezia.

Heras, A., \& Lasagabaster, D. (2015). The Impact of CLIL on Affective

Factors and Vocabulary Learning. Language Teaching Research, 19(1), 70-88. doi:10.1177/1362168814541736

Johnson, D. W., \& Johnson, R.T. (1989). Cooperation and competition:

Theory and research. Edina, MN: Interaction Book Co.

Kagan, S. (1985). Cooperative Learning. Resources for Teachers. Riverside,

CA: University of California.

Kagan, S. (1995). We Can talk: Cooperative Learning in the Elementary ESL

Classroom. Washington, DC: ERIC Clearinghouse on Languages and Linguistics.

Kozar, O. (2010). Towards Better Group Work: Seeing the Difference between Cooperation and Collaboration. English Teaching Forum, 2, 16-23.

Long, M., \& Porter, P. (1985). Group Work, Interlanguage Talk, and Second Language Acquisition. TESOL Quarterly, 19, 207-28.

doi:10.2307/3586827

Markham, T. (2011). Project Based Learning. Teacher Librarian, 39(2), 3842.

McCafferty, S. G., Jacobs, G. M., \& Iddings, A. C. (2006). Cooperative Learning and Second Language Teaching. Cambridge: Cambridge University Press.

McInnerney, J. M., \& Roberts, T. S. (2004). Collaborative or Cooperative Learning? In T.S. Roberts (Ed.), Online Collaborative Learning: Theory and Practice (pp. 203-14). Hershey, PA: Information Science Publishing.

McWhaw, K., Schnackenberg, H., Schlater, J., \& Abrami P. C. (2003). From Cooperation to Collaboration: Helping Students Become Collaborative Learners". In R. Gillies, A. Ashman, (Eds.), The Social and Intellectual Outcomes of Learning in Groups (pp. 69-86). London: Routledge Falmer.

Marsh, D. (2013). The CLIL Trajectory: Educational Innovation for the 21th

Century iGeneration. Córdoba: University of Cordoba Academic Press.

Meyer, O. (2010). Towards Quality-CLIL: Successful Planning and Teaching Strategies. Puls, 33, 11-29. 
Navés, T., \& Muñoz, C. (2000). Usar las lenguas para aprender y aprender a usar las lenguas extranjeras. Una introducción al AICLE para madres, padres y jóvenes. In D. Marsh \& G. Langé (Eds.), Using Languages to Learn and Learning to Use Language (pp. 1-16). Jyväskylá: UniCOM, University of Jyväskylä on behalf of TIE-CLIL. Part 3.

Pastor, M. R. (2011). CLIL and Cooperative Learning. Encuentro, 20, 109118.

Pavón, V., \& Ellison, M. (2013). Examining Teacher Roles and Competences in Content and Language Learning (CLIL). Linguarum Arena, 4, 6578.

Pavón, V., Ávila, F. J., Espejo, R., \& Gallego, A. (2014). Strategic and Organisational Decisions in Planning CLIL: a Study on the Collaboration Between Content and Language Teachers. International Journal of Bilingual Education and. Bilingualism, advance access. doi:10.1080/13670050.2014.909774

Pavón, V., Prieto, M., \& Ávila, J. (2015). Perceptions of Teachers and Students of the Promotion of Interaction and Cooperative Learning Through Task-based Activities in CLIL. Porta Linguarum, 23, 75-91. Pena, C., \& Porto, M.D. (2007). Teacher Beliefs in a CLIL Education Project. Porta Linguarum, 10, 151-161.

Pérez-Cañado, M. L. (2014). Teacher Training Needs for Bilingual Education: In-service Teacher Perceptions, International Journal of Bilingual Education and Bilingualism, advance access.

doi:10.1080/13670050.2014.980778

Pica, T., Lincoln-Porter, F., Paninos, D., \& Linell, J. (1996). Language

Learners Interaction: How Does it Address the Input, Output, and Feed-back Needs of L2 Learners. TESOL Quaterly, 30(1), 59 - 84. doi:10.2307/3587607

Poisel, E. (2012). Competence Development Through Task-based Learning. In D. Marsh \& O. Meyer (Eds.), Quality Interfaces: Examining Evidence \& Exploring Solutions in CLIL (pp. 251-263). Eichstätt: Eichstätt Academic Press.

Roberts, T. S., \& McInnerney, J. M. (2007). Seven Problems of Online Group Learning (and Their Solutions). Educational Technology \& Society, 10(4), 257-268. 
164 Ramos \& Pavón - Developing Cooperative Learning \& CLIL

Roschelle, J., \& Teasley, S. (1995). The Construction of Shared Knowledge in Collaborative Problem Solving. In C.E. O'Malley (Ed.), Computer supported collaborative learning (pp. 69-67). Heidelberg: Springer-

Verlag.

Segovia, I., Lupiáñez, J. L., Molina, M., González, F., Miñán, A., \& Real, I. (2010). The Conception and Role of Interdisciplinarity in the Spanish Education System. Issues in Integrative Studies, 28, 138-69.

Seliger, H. W., \& Shohamy, E. (1989). Second Language Research Methods. Oxford: Oxford University Press.

Skehan, P. (1998). Task-based Instruction. Cambridge: Cambridge University Press.

Slavin, R. E. (1995). Cooperative Learning: Theory, Research, and Practice. 2nd ed. Boston: Allyn and Bacon.

Smith, K. A. (1995). Cooperative Learning: Effective Teamwork for Engineering Classrooms. Paper presented at the annual ASEE/IEEE Frontiers in Education Conference, Atlanta. Retrieved from http://fieconference.org/fie $95 / 2 b 5 / 2$ b54/2b54.htm

Willis, J. (1996). A Theoretical Framework for Task-Based Learning.

Harlow: Longman.

Willis, J., \& Willis, D. (1996). Challenge and Change in Language

Teaching. Oxford: Heinemann.

Willis, J., \& Willis, D. (2007). Doing Task-based Teaching. Oxford: Oxford University Press.

María del Carmen Ramos Ordóñez is a Primary education teacher at the Manuel Siurot Primary School and a doctorate student at the University of Cordoba.

Víctor Pavón Vázquez is Senior Lecturer and Coordinator of the Bilingual Programme at the University of Cordoba.

Contact Address: Víctor Pavón Vázquez. Department of English and German Philology. Faculty of Humanities. University of Córdoba. Plaza del Cardenal Salazar, 3, 14071, Córdoba, Spain.

Email: victor.pavon@uco.es 


\section{Appendix A \\ Teachers' questionnaire}

Question 1. When the school year started, did you feel confident when working through tasks?

- Yes

- No

Can you state your reasons?

Question 2. If this is your first year in this school, had you worked previously through tasks or projects?

- Yes

- No

Question 3. What are the greatest difficulties that you find in the use of tasks?

Question 4. After the development of goals in all the didactic units, has it been possible to elaborate a final product in all the didactic units?

- Yes

- No

Question 5. If the answer to the previous question is 'no' specify the reasons why it has not been possible to achieve the goals in all the didactic units:

- Difficulty to adjust the contents and activities to the quarterly/yearly timing.

- Difficulties to adapt my teaching practice to this system of work.

- Difficulties in accessing to suitable materials and resources.

- Because of the difficulty that students have to work cooperatively.

- Others:

Question 6. In your opinion, taking into account the areas you teach, how many of the students achieved the didactic objectives selected for each task?

Very few Some Many all of them

Question 7. On a scale of 1-10, with 10 being the highest mark, value the effectiveness of tasks as a methodological strategy in CLIL to promote students' involvement.

$\begin{array}{llllllllll}1 & 2 & 3 & 4 & 5 & 6 & 7 & 8 & 9 & 10\end{array}$


166 Ramos \& Pavón-Developing Cooperative Learning \& CLIL

Question 8. In your opinion, which skills have improved and how?

\begin{tabular}{|l|l|l|l|}
\cline { 2 - 4 } \multicolumn{1}{c|}{} & Very little & Something & A lot \\
\hline Listening & & & \\
\hline Speaking & & & \\
\hline Reading & & & \\
\hline Writing & & & \\
\hline Interaction & & & \\
\hline
\end{tabular}

Question 9. Has there been coordination with the rest of the teachers of linguistic areas and content areas? If so, specify how (by e-mail, in the afternoon schedule, in coordination schedule) and how it worked.

Question10. Has there been coordination and planning of the classes with the language assistants? If so, of what type?

Question 11: At this current time, what is your motivation towards this project? Will you carry on with it? 